\title{
INVESTIGATION OF THE EFFECT OF PHYSICAL ACTIVITY LEVELS ON QUALITY OF LIFE OF PATIENTS WITH COVID -19i
}

\author{
Canan Sever, \\ Frrat Akcan ii \\ Gaziantep University, \\ Physical Education and Sport Faculty, \\ Gaziantep, Turkey
}

\begin{abstract}
:
It is thought that knowing the situations that minimize the negative effects of Covid-19 on human health will be useful in the fight against the epidemic. In this study, it was aimed to investigate the relationship between the level of physical activity and the effect of Covid-19 on quality of life. 200 people who had previously had Covid-19 participated in the study voluntarily. An international physical activity questionnaire was applied to the participants to determine their pre-disease physical activity levels, and an international quality of life scale was applied to determine the effect of Covid-19 on the quality of life during the disease. SPSS 22 package program was used in the analysis of the data. In the study, the relationship between age, marital status, gender, education and physical activity level and the effect of Covid-19 disease on quality of life was examined. There was no statistically significant difference between the age, gender and marital status of the participants and the scores they got from the quality-of-life questionnaire $(p<0.05)$. On the other hand, there was a statistically significant difference between the education levels of the participants and the scores they received from the quality of life, between those who received high school education and those who received education at the undergraduate level, in favor of those who received undergraduate education, in general health scores and social health scores $(\mathrm{p}<0.05)$. On the other hand, the general health score between the physical activity level and the quality-of-life scores, the physical activity level between the active and the very active, in favor of the very active, the general health score between the inactive and the active and the very active, the general health score in favor of the active and very active statistically significant difference was found $(p<0.05)$. As a result, it can be said that those with good educational status and those with active and very active physical activity levels are more advantageous in
\end{abstract}

\footnotetext{
i This article was adapted from the master thesis named Investigation of the Effect of Physical Activity Levels on Quality of Life of Patients with Covid -19.

ii Correspondence: email akcanfirat@yahoo.com
} 
feeling less of the symptoms associated with Covid-19 and reducing its negative impact on quality of life.

Keywords: Covid-19, physical activity, quality of life

\section{Introduction}

The Covid-19 epidemic has affected our country as well as the whole world and has caused problems in almost every field. Covid-19 is a virus-borne disease and has turned into an epidemic that has very different symptoms and threatens human health significantly ( $\underline{1})$.

In this study, it was aimed to investigate the relationship between the level of physical activity and the effect of Covid-19 on quality of life.

First, cases of shortness of breath and respiratory tract infection of unknown cause were detected on 31 December 2019 in the city of Wuhan, China. Initial cases were classified as 'pneumonia of unknown origin' because the diagnosis was not made immediately (2). After the research, a new virus belonging to the coronavirus (CoV) family was announced as the disease agent (2). On February 11, 2020, the WHO DirectorGeneral announced the disease caused by Covid-19, which was seen for the first time, as the abbreviation of "corona virus disease 2019" and the isolation process as "COVID-19 disease" (므).

It was stated that as of 6 May 2020, there were more than 250,000 deaths and more than 3.7 million confirmed cases of COVID-19 worldwide, including more than 200 countries and regions ( $\underline{4})$. As of August 2020, the total death caused by the epidemic, which is still ongoing today, is over 800 thousand in the world, 6 thousand in Turkey, the total number of cases is over 23 million in the world and over 260 thousand in Turkey (므). The COVID-19 pandemic and the developments after it has become a situation that affects the world in many respects, especially in health, economy, education, transportation, agriculture, etc. It is thought that the ongoing corona pandemic process may have economic and political effects, as well as serious effects on people's social, psychological, physical and mental health, as well as on the economy of our country and the World ( $\underline{6})$.

Scientific studies are of great importance in order to reduce the negative effects of this rather new epidemic. In our study, the quality-of-life levels of the patients in the Covid-19 process were determined and compared with the physical activity levels before the disease. In this way, it has been tried to find the answer whether the level of physical activity has an effect on reducing the negative effects of Covid-19 disease on the quality of life. In addition, the quality-of-life scores of the patients in the covid 19 process with age, gender, educational status and marital status were also compared and it was also investigated whether there was a relationship with the mentioned variables. 


\section{Material and Method}

\subsection{Purpose and Model of the Research}

This study was carried out using a scanning design, one of the qualitative research methods. This study was carried out to examine the relationship between the level of physical activity and the level of being affected by the Covid-19 disease. In the study, the physical activity levels of the participants were determined by applying the International Physical Activity Questionnaire Short Form in order to determine the pre-weekly physical activity levels of individuals who had recently had Covid-19 disease, and then the World Health Organization Quality of Life Scale Short Form (SF 36) was applied during the period of covid-19 disease. tried to determine the quality of life. Finally, the relationship between the quality of life and the level of physical activity during the period of Covid-19 disease was examined.

\subsection{Universe and Sample}

The population of this study is people who have had Covid-19 disease. The sample consists of 200 volunteer participants living within the borders of Gaziantep province.

\subsection{Data Collection}

\subsubsection{International Physical Activity Questionnaire Short Form}

In order to determine the physical activity levels of the participants in the study; “International Physical Activity Assessment Questionnaire Short Form (IPAQ Short Form - International Physical Activity Questionnaire Short Form) was used (ㅁ).

\subsubsection{World Health Organization Quality of Life Scale Short Form Turkish Version}

"World Health Organization Quality of Life Scale Short Form Turkish Version (WHOQOL-BREF-TR)" was used in order to determine the quality of life of the participants who contracted the Covid-19 disease during the disease process. The long form of the scale consists of 100 questions and the short form consists of 26 questions. The Turkish validity and reliability study of the scale was carried out by Eser et al. (1999). There are 26 questions in the scale that measure the physical health, mental health, social health and environmental well-being of the participants (ㅁ).

\subsection{Data Analysis}

SPSS statistical program (SPSS for Windows, version 20.0, 2008, SPSS Inc. Chicago, Illinois, USA) was used for data analysis. Data were evaluated according to $95 \%$ confidence interval $(\mathrm{p}<0.05)$. The mean value and standard deviation values were used for the descriptive parameters of the participants. Shapiro Wilk and Kolmogorov Smirnov tests were used to test the normality of the data sets.

In data sets with 2 groups, Independent Sample $\mathrm{T}$ test was used for normally distributed data sets, and Man Whitney U test was used for data sets that did not show normal distribution. One Way ANOVA test was used for normally distributed datasets 
where the number of groups is more than 2, Kruskal Wallis test was used for datasets that did not show normal distribution, and the LSD test was used to determine which group the significance was in.

\section{Results}

Table 1: Descriptive parameters of the participants

\begin{tabular}{|c|c|c|c|}
\hline \multicolumn{2}{|l|}{ Variables } & $\mathbf{N}$ & $\%$ \\
\hline \multirow[t]{2}{*}{ Gender } & Male & 119 & 59,5 \\
\hline & Female & 81 & 40,5 \\
\hline \multirow{6}{*}{$\begin{array}{l}\text { Marital } \\
\text { Status }\end{array}$} & Never married & 123 & 61,5 \\
\hline & Living like married & 5 & 2,5 \\
\hline & The married & 66 & 33,00 \\
\hline & Divorced & 2 & 0,1 \\
\hline & Divided & 3 & 1,5 \\
\hline & His wife does not live & 1 & 0,5 \\
\hline \multirow[t]{4}{*}{ Age } & 18-21 ages & 38 & 19,00 \\
\hline & 22-25 ages & 55 & 27,05 \\
\hline & 26-34 ages & 55 & 27,05 \\
\hline & 35 ages and above & 52 & 26,00 \\
\hline \multirow{4}{*}{$\begin{array}{l}\text { Educational } \\
\text { Status }\end{array}$} & High school & 54 & 27,00 \\
\hline & Associate degree & 26 & 13,00 \\
\hline & Undergraduate & 93 & 46,5 \\
\hline & Post graduate & 27 & 13,5 \\
\hline \multirow{3}{*}{$\begin{array}{l}\text { Physical } \\
\text { Activity } \\
\text { Level }\end{array}$} & Inactive & 121 & 60,5 \\
\hline & Active & 68 & 34,00 \\
\hline & Very active & 11 & 5,5 \\
\hline
\end{tabular}

When Table 1 is examined, it is seen that 119 (59.5\%) of the participants are male and 81 $(49.5 \%)$ of them are female. On the other hand, the marital statuses were 123 never married (61.5\%), living as if married $5(2.5 \%)$, married $66(33.0 \%)$, divorced $2(0.1 \%)$, separated $3(1.5 \%)$, spouse does not live $1(0.5 \%)$. When looking at the age range, 38 people (19.0\%) aged 18-21, 55 people aged 22-25 (27.0\%), 55 people aged 26-34 (27.5\%) 52 people aged 35 and over. It is seen that it is $26.0 \%$. In terms of education, there are 54 high school students $(27.0 \%)$, associate degree $26(13.0 \%)$, undergraduate $26(46.5 \%)$, and postgraduate $27(13.5 \%)$. When the physical activity levels are considered, it is seen that there are 121 inactive people (60.5\%), active 68 people $(34.0 \%)$, and 11 very active people $(5.5 \%)$. 
Table 2: Comparison of the Gender variable and the mean scores of

the participants from the Quality-of-Life Scale (Independent Sample T Test)

\begin{tabular}{|c|c|c|c|c|c|c|}
\hline & Gender & $\mathbf{N}$ & Mean. & Std. Dev. ( \pm ) & $t$ & $p$ \\
\hline \multirow{2}{*}{$\begin{array}{l}\text { General } \\
\text { Health }\end{array}$} & Male & 119 & 52,20 & 19,16 & \multirow{2}{*}{0,234} & \multirow{2}{*}{0,815} \\
\hline & Female & 81 & 51,54 & 20,38 & & \\
\hline \multirow{2}{*}{$\begin{array}{l}\text { Physical } \\
\text { Health }\end{array}$} & Male & 119 & 49,81 & 12,16 & \multirow{2}{*}{$-0,556$} & \multirow{2}{*}{0,579} \\
\hline & Female & 81 & 50,79 & 12,12 & & \\
\hline \multirow{2}{*}{$\begin{array}{l}\text { Psychological } \\
\text { Health }\end{array}$} & Male & 119 & 56,37 & 14,08 & \multirow{2}{*}{0,733} & \multirow{2}{*}{0,464} \\
\hline & Female & 81 & 54,83 & 15,23 & & \\
\hline \multirow{2}{*}{$\begin{array}{l}\text { Social } \\
\text { Health }\end{array}$} & Male & 119 & 53,79 & 17,89 & \multirow{2}{*}{$-0,196$} & \multirow{2}{*}{0,844} \\
\hline & Male & 81 & 54,32 & 19,28 & & \\
\hline \multirow{2}{*}{$\begin{array}{l}\text { Environmental } \\
\text { Health }\end{array}$} & Female & 119 & 54,22 & 13,84 & \multirow{2}{*}{0,386} & \multirow{2}{*}{0,700} \\
\hline & Male & 81 & 53,43 & 14,95 & & \\
\hline
\end{tabular}

When Table 2 is examined, no statistically significant difference was found between the total mean scores of the participants' quality of life in terms of gender variable $(p<0.05)$.

Table 3: Comparison of Participants' Educational Status Variable and Mean Scores from the Quality-of-Life Scale (One Way ANOVA Test)

\begin{tabular}{|c|c|c|c|c|c|c|}
\hline & & $\mathbf{N}$ & Mean. & Std. Dev. ( \pm ) & $\mathrm{p}$ & Significant Difference \\
\hline \multirow{4}{*}{$\begin{array}{l}\text { General } \\
\text { Health }\end{array}$} & High school (1) & 54 & 45,37 & 20,50 & \multirow{4}{*}{0,007} & \multirow{4}{*}{ C } \\
\hline & Associate degree (2) & 26 & 48,07 & 20,82 & & \\
\hline & Undergraduate (3) & 93 & 56,31 & 17,54 & & \\
\hline & Post Graduate (4) & 27 & 53,70 & 20,10 & & \\
\hline \multirow{4}{*}{$\begin{array}{l}\text { Physical } \\
\text { Health }\end{array}$} & High school (1) & 54 & 49,33 & 12,010 & \multirow{4}{*}{0,917} & \multirow{4}{*}{-} \\
\hline & Associate degree (2) & 26 & 51,09 & 13,00 & & \\
\hline & Undergraduate (3) & 93 & 50,26 & 12,23 & & \\
\hline & Post Graduate (4) & 27 & 50,92 & 11,66 & & \\
\hline \multirow{4}{*}{$\begin{array}{l}\text { Psychological } \\
\text { Health }\end{array}$} & High school (1) & 54 & 54,24 & 16,17 & \multirow{4}{*}{0,053} & \multirow{4}{*}{-} \\
\hline & Associate degree (2) & 26 & 50,16 & 15,34 & & \\
\hline & Undergraduate (3) & 93 & 58,42 & 12,48 & & \\
\hline & Post Graduate (4) & 27 & 54,93 & 15,63 & & \\
\hline \multirow{4}{*}{$\begin{array}{l}\text { Social } \\
\text { Health }\end{array}$} & High school (1) & 54 & 52,46 & 19,66 & \multirow{4}{*}{0,008} & \multirow{4}{*}{$2-3$} \\
\hline & Associate degree (2) & 26 & 44,55 & 17,62 & & \\
\hline & Undergraduate (3) & 93 & 57,97 & 17,58 & & \\
\hline & Post Graduate (4) & 27 & 52,54 & 16,22 & & \\
\hline \multirow{4}{*}{$\begin{array}{l}\text { Environmental } \\
\text { Health }\end{array}$} & High school (1) & 54 & 52,02 & 15,69 & \multirow{4}{*}{0,361} & \multirow{4}{*}{-} \\
\hline & Associate degree (2) & 26 & 51,20 & 16,81 & & \\
\hline & Undergraduate (3) & 93 & 55,07 & 12,32 & & \\
\hline & Post Graduate (4) & 27 & 56,25 & 14,88 & & \\
\hline
\end{tabular}

When Table 3 is examined, a statistically significant difference was found between the high school group and the undergraduate group in favor of the undergraduate group in the mean scores of the participants in the quality-of-life scale in terms of the education level variable, and in the general health score $(\mathrm{p}<0.05)$. Similarly, a statistically significant difference was found between the high school group and the undergraduate group in social health scores in favor of the undergraduate group $(p<0.05)$. 
Table 4: Comparison of Participants' Age Variable and Average Scores from the Quality-of-Life Scale (One Way ANOVA Test)

\begin{tabular}{|c|c|c|c|c|c|c|}
\hline & & $\mathbf{N}$ & Mean. & Std. Dev. ( \pm ) & p & Significant Difference \\
\hline \multirow{4}{*}{$\begin{array}{l}\text { General } \\
\text { Health }\end{array}$} & 18-21 age & 38 & 49,34 & 19,69 & \multirow{4}{*}{0,827} & \multirow[t]{4}{*}{ C } \\
\hline & $22-25$ age & 55 & 52,50 & 20,60 & & \\
\hline & 26-29 age & 55 & 52,04 & 19,05 & & \\
\hline & 35 ve age and above & 52 & 53,12 & 19,47 & & \\
\hline \multirow{4}{*}{$\begin{array}{l}\text { Physical } \\
\text { Health }\end{array}$} & 18-21 age & 38 & 52,25 & 11,81 & \multirow{4}{*}{0,723} & \multirow{4}{*}{-} \\
\hline & 22-25 age & 55 & 49,87 & 12,21 & & \\
\hline & 26-29 age & 55 & 49,67 & 12,39 & & \\
\hline & 35 ve age and above & 52 & 49,65 & 12,17 & & \\
\hline \multirow{4}{*}{$\begin{array}{l}\text { Psychological } \\
\text { Health }\end{array}$} & 18-21 age & 38 & 57,23 & 14,90 & \multirow{4}{*}{0,374} & \multirow{4}{*}{-} \\
\hline & 22-25 age & 55 & 56,36 & 14,54 & & \\
\hline & 26-29 age & 55 & 56,96 & 14,02 & & \\
\hline & 35 ve age and above & 52 & 52,72 & 14,78 & & \\
\hline \multirow{4}{*}{$\begin{array}{l}\text { Social } \\
\text { Health }\end{array}$} & 18-21 age & 38 & 59,21 & 19,83 & \multirow{4}{*}{0,214} & \multirow{4}{*}{-} \\
\hline & $22-25$ age & 55 & 54,24 & 17,92 & & \\
\hline & $26-29$ age & 55 & 52,87 & 18,71 & & \\
\hline & 35 ve age and above & 52 & 51,16 & 17,27 & & \\
\hline \multirow{4}{*}{$\begin{array}{l}\text { Environmental } \\
\text { Health }\end{array}$} & 18-21 age & 38 & 55,42 & 17,00 & \multirow{4}{*}{0,298} & \multirow{4}{*}{-} \\
\hline & $22-25$ age & 55 & 52,44 & 13,81 & & \\
\hline & 26-29 age & 55 & 51,93 & 12,43 & & \\
\hline & 35 ve age and above & 52 & 56,43 & 14,29 & & \\
\hline
\end{tabular}

When Table 4 is examined, no statistically significant difference was found between the groups in the mean scores of the participants from the quality-of-life scale in terms of the age variable $(\mathrm{p}<0.05)$.

Table 5: Comparison of the Mean Scores of the Participants from the Marital Status Variable and the Quality-of-Life Scale (One Way ANOVA Test)

\begin{tabular}{|c|c|c|c|c|c|c|}
\hline & & $\mathbf{N}$ & Mean. & Std. Dev. ( \pm ) & $\mathrm{p}$ & Significant Difference \\
\hline \multirow{6}{*}{$\begin{array}{l}\text { General } \\
\text { Health }\end{array}$} & Never married & 123 & 53,04 & 19,02 & \multirow{6}{*}{0,445} & \multirow{6}{*}{ C } \\
\hline & Living like married & 5 & 62,50 & 8,83 & & \\
\hline & The married & 66 & 48,48 & 21,31 & & \\
\hline & Divorced & 2 & 62,50 & 8,83 & & \\
\hline & Divided & 3 & 54,16 & 19,09 & & \\
\hline & His wife does not live & 1 & 62,50 & 21,31 & & \\
\hline \multirow{6}{*}{$\begin{array}{l}\text { Physical } \\
\text { Health }\end{array}$} & Never married & 123 & 51,30 & 10,35 & \multirow{6}{*}{0,173} & \multirow{6}{*}{-} \\
\hline & Living like married & 5 & 55,00 & 6,96 & & \\
\hline & The married & 66 & 47,29 & 15,06 & & \\
\hline & Divorced & 2 & 50,00 & 8,75 & & \\
\hline & Divided & 3 & 59,52 & 7,43 & & \\
\hline & His wife does not live & 1 & 57,14 & 5,63 & & \\
\hline \multirow{6}{*}{$\begin{array}{l}\text { Psychological } \\
\text { Health }\end{array}$} & Never married & 123 & 56,36 & 14,61 & \multirow{6}{*}{0,386} & \multirow{6}{*}{-} \\
\hline & Living like married & 5 & 66,66 & 4,16 & & \\
\hline & The married & 66 & 53,66 & 14,95 & & \\
\hline & Divorced & 2 & 56,25 & 14,73 & & \\
\hline & Divided & 3 & 61,11 & 6,36 & & \\
\hline & His wife does not live & 1 & 45,83 & 4,62 & & \\
\hline \multirow{3}{*}{$\begin{array}{l}\text { Social } \\
\text { Health }\end{array}$} & Never married & 123 & 54,89 & 18,76 & \multirow{3}{*}{0,118} & \multirow{3}{*}{-} \\
\hline & Living like married & 5 & 53,33 & 13,94 & & \\
\hline & The married & 66 & 52,90 & 17,26 & & \\
\hline
\end{tabular}


LEVELS ON QUALITY OF LIFE OF PATIENTS WITH COVID -19

\begin{tabular}{|l|l|c|c|c|c|c|}
\hline \hline \multirow{5}{*}{$\begin{array}{l}\text { Environmental } \\
\text { Health }\end{array}$} & Divorced & 2 & 29,16 & 29,46 & \multirow{2}{*}{} & \\
\cline { 2 - 5 } & Divided & 3 & 69,44 & 17,34 \\
\cline { 2 - 5 } & His wife does not live & 1 & 25,00 & 5,96 & & \\
\cline { 2 - 5 } & Never married & 123 & 54,75 & 14,06 & & \\
\cline { 2 - 5 } & Living like married & 5 & 61,87 & 11,13 & & \\
\cline { 2 - 5 } & The married & 66 & 52,27 & 14,89 & & \\
\cline { 2 - 5 } & Divorced & 2 & 42,18 & 11,04 & \\
\cline { 2 - 5 } & Divided & 3 & 52,08 & 14,43 & & \\
\cline { 2 - 5 } & His wife does not live & 1 & 46,87 & 11,25 & & \\
\hline
\end{tabular}

When Table 5 is examined, no statistically significant difference was found between the groups in the mean scores of the participants from the quality-of-life scale in terms of the marital status variable $(\mathrm{p}<0.05)$.

Table 6: Comparison of the average scores of the participants from the Quality of Life scale according to the Variable of Physical Activity Level (One Way ANOVA Test)

\begin{tabular}{|c|c|c|c|c|c|c|}
\hline & & $\mathbf{N}$ & Mean. & Std. Dev. ( \pm ) & p & Significant Difference \\
\hline \multirow{3}{*}{$\begin{array}{l}\text { General } \\
\text { Health }\end{array}$} & Inactive (1) & 121 & 49,17 & 18,66 & \multirow{3}{*}{0,006} & \multirow{3}{*}{$1-3,2-3$} \\
\hline & Active (2) & 68 & 54,41 & 20,00 & & \\
\hline & Very active (3) & 11 & 67,04 & 20,36 & & \\
\hline \multirow{3}{*}{$\begin{array}{l}\text { Physical } \\
\text { Health }\end{array}$} & Inactive (1) & 121 & 48,90 & 12,48 & \multirow{3}{*}{0,156} & \multirow{3}{*}{-} \\
\hline & Active (2) & 68 & 51,99 & 11,04 & & \\
\hline & Very active (3) & 11 & 53,57 & 13,64 & & \\
\hline \multirow{3}{*}{$\begin{array}{l}\text { Psychological } \\
\text { Health }\end{array}$} & Inactive (1) & 121 & 56,47 & 13,66 & \multirow{3}{*}{0,580} & \multirow{3}{*}{-} \\
\hline & Active (2) & 68 & 55,02 & 15,19 & & \\
\hline & Very active (3) & 11 & 52,27 & 19,92 & & \\
\hline \multirow{3}{*}{$\begin{array}{l}\text { Social } \\
\text { Health }\end{array}$} & Inactive (1) & 121 & 53,85 & 18,78 & \multirow{3}{*}{0,970} & \multirow{3}{*}{-} \\
\hline & Active (2) & 68 & 54,41 & 18,29 & & \\
\hline & Very active (3) & 11 & 53,21 & 16,54 & & \\
\hline \multirow{3}{*}{$\begin{array}{l}\text { Environmental } \\
\text { Health }\end{array}$} & Inactive (1) & 121 & 53,48 & 14,64 & \multirow{3}{*}{0,823} & \multirow{3}{*}{-} \\
\hline & Active (2) & 68 & 54,77 & 13,52 & & \\
\hline & Very active (3) & 11 & 53,12 & 15,62 & & \\
\hline
\end{tabular}

When Table 2 is examined, a statistically significant difference was found between the group with very active physical activity level and those with active or inactive physical activity level in favor of the group with very active general health score $(p<0.05)$. On the other hand, no statistically significant difference was found between the groups in other sub-dimensions $(\mathrm{p}<0.05)$.

\section{Discussion}

The findings obtained in this part of the study were discussed by comparing them with similar studies in the literature, and suggestions were presented in the last section.

There was no statistically significant difference between the age, gender and marital status of the participants and the scores they got from the quality-of-life questionnaire $(\mathrm{p}<0.05)$. On the other hand, there was a statistically significant difference between the education levels of the participants and the scores they received from the 
quality of life, between those who received high school education and those who received education at the undergraduate level, in favor of those who received undergraduate education, in general health scores and social health scores $(\mathrm{p}<0.05)$. On the other hand, the general health score between the physical activity level and the quality-of-life scores, the physical activity level between the active and the very active, in favor of the very active, the general health score between the inactive and the active and the very active, the general health score in favor of the active and very active. statistically significant difference was found $(\mathrm{p}<0.05)$.

Tunç et al. (2020), in their study called The Effect of Exercise on Quality of Life during the Covid 19 Epidemic, reported that those who exercise were less affected by Covid-19 than those who did not exercise (ㅁ).

Leandro et al. (2020), in their study examining the relationship between Covid-19 and Exercise, reported that moderate and low-intensity exercise can be effective in alleviating the symptoms associated with the disease by positively affecting the immune system $(\underline{10})$.

Colley et al. (2020), in their study examining the effects of regular exercise during the Covid-19 process, reported that the quality of life of those who exercise regularly is beneficial in terms of general health and mental health (11).

Simpson et al. (2020), in their study examining the relationship between exercise and immune system, reported that moderate and low-intensity exercise can be effective in alleviating the symptoms that occur due to diseases by positively affecting the immune system (12).

Chen et al. (2020), in their study on the importance of exercise during the Covid19 epidemic, emphasized that staying at home for a long time during the epidemic management process may lead to negative consequences due to a sedentary lifestyle, and stated and recommended that regular exercise should be continued at home as well. However, they emphasized that regular exercises can also help alleviate the negative symptoms that may occur due to Covid-19 disease (13).

Ricci et al. (2020) emphasized that it is extremely important to stay physically active in their studies, where they mentioned the possible risks of staying at home during the Covid-19 epidemic, and stated that the symptoms that will occur due to Covid-19 may be more severe depending on the decrease in physical activity (14).

Lippi et al. (2020), in their study examining cardiovascular problems that may arise due to lack of physical activity during the Covid-19 epidemic, reported that Covid19 causes symptoms that adversely affect cardiopulmonary and cardiovascular. For this reason, they stated that being physically active can be beneficial in reducing the negative effects of Covid-19 due to its positive effects on the cardiovascular and cardiopulmonary system $(\underline{15})$.

The above-mentioned literature studies support the findings of our study. Various scientific studies have shown that exercise contributes to the strengthening of the immune system and thus helps fight diseases (16). It is thought that the results of our findings arise due to this situation. 
During the Covid-19 epidemic, it has become very difficult to access areas where exercise can be done due to both the closures and the measures taken. This situation increases the risk of cardiovascular diseases due to lack of physical activity in individuals and may cause weakening of the immune system (15). During the Covid-19 disease period, the disease may progress more severely due to weakened immune system and cardiovascular system disorders, and quality of life may be adversely affected (13).

As a result, it is thought that staying as physically active as possible and increasing the level of education during the epidemic process may be beneficial in reducing the negative effects that may arise due to Covid-19 and in reducing the negative impact of this situation on the quality of life.

It is thought that conducting similar studies in larger groups may contribute to the scientific literature. In addition, it is thought that it may be useful to conduct research on the course of the disease in sports groups. It is thought that conducting studies on the effect of different exercise types on the Covid-19 disease process can contribute to the scientific literature.

\section{Conflict of Interest Statement}

There are no potential conflicts of interest on this article.

\section{About the Authors}

Canan Sever has Master of Science degree in sport science research field.

Firat Akcan is an Associate Professor Doctor at Gaziantep University, Turkey.

\section{References}

1. Cascella M, Rajnik M, Aleem A, Dulebohn S, Di Napoli R. Features, evaluation, and treatment of coronavirus (COVID-19). StatPearls. 2021.

2. Lu H, Stratton CW, Tang YW. Outbreak of pneumonia of unknown etiology in Wuhan, China: The mystery and the miracle. Journal of medical virology. 2020;92(4):401.

3. Corman VM, Landt O, Kaiser M, Molenkamp R, Meijer A, Chu DK, et al. Detection of 2019 novel coronavirus (2019-nCoV) by real-time RT-PCR. Eurosurveillance. 2020;25(3):2000045.

4. Malay DS. COVID-19, pandemic, and social distancing. The Journal of Foot and Ankle Surgery. 2020;59(3):447.

5. Choi EPH, Hui BPH, Wan EYF. Depression and anxiety in Hong Kong during COVID-19. International journal of environmental research and public health. 2020;17(10):3740.

6. Örgütü DS. Turkey: WHO Coronavirus disease (COVID-19) dashboard. 2020. 
7. Lee PH, Macfarlane DJ, Lam TH, Stewart SM. Validity of the international physical activity questionnaire short form (IPAQ-SF): A systematic review. International Journal of Behavioral Nutrition and Physical Activity. 2011;8(1):1-11.

8. Eser SY, Fidaner H, Fidaner C, Elbi H, Eser E, Göker E. Measure of quality of life WHOQOL-100 and WHOQOL-Bref. 3P Dergisi. 1999;7(2 Suppl):5-13.

9. Tunç AÇ, Zorba E, Çingöz YE. Covid 19 salgını döneminde egzersizin yaşam kalitesine etkisi. Uluslararası Güncel Eğitim Araştırmaları Dergisi. 2020;6(1):12735.

10. Leandro CG, e Silva WTF, Lima-Silva AE. Covid-19 and exercise-induced immunomodulation. Neuroimmunomodulation. 2020:1.

11. Colley RC, Bushnik T, Langlois K. Exercise and screen time during the COVID-19 pandemic. Health Rep. 2020;31(6):3-11.

12. Simpson RJ, Campbell JP, Gleeson M, Krüger K, Nieman DC, Pyne DB, et al. Can exercise affect immune function to increase susceptibility to infection? Exercise immunology review. 2020;26:8-22.

13. Chen P, Mao L, Nassis GP, Harmer P, Ainsworth BE, Li F. Coronavirus disease (COVID-19): The need to maintain regular physical activity while taking precautions. Journal of sport and health science. 2020;9(2):103.

14. Ricci F, Izzicupo P, Moscucci F, Sciomer S, Maffei S, Di Baldassarre A, et al. Recommendations for physical inactivity and sedentary behavior during the coronavirus disease (COVID-19) pandemic. Frontiers in public health. 2020;8:199.

15. Lippi G, Henry BM, Sanchis-Gomar F. Physical inactivity and cardiovascular disease at the time of coronavirus disease 2019 (COVID-19). European journal of preventive cardiology. 2020;27(9):906-8.

16. Ersöz G, Köksoy A, Zergeroğlu AM, Yavuzer S. Akut-Kronik Fiziksel Egzersiz ve Immunglobulinler. Spor bilimleri dergisi. 1995;6(3):3-12. 
Creative Commons licensing terms

Authors will retain the copyright of their published articles agreeing that a Creative Commons Attribution 4.0 International License (CC BY 4.0) terms will be applied to their work. Under the terms of this license, no permission is required from the author(s) or publisher for members of the community to copy, distribute, transmit or adapt the article content, providing a proper, prominent and unambiguous attribution to the authors in a manner that makes clear that the materials are being reused under permission of a Creative Commons License. Views, opinions and conclusions expressed in this research article are views, opinions and conclusions of the author(s). Open Access Publishing Group and European Journal of Physical Education and Sport Science shall not be responsible or answerable for any loss, damage or liability caused in relation to/arising out of conflict of interests, copyright violations and inappropriate or inaccurate use of any kind content related or integrated on the research work. All the published works are meeting the Open Access Publishing requirements and can be freely accessed, shared, modified, distributed and used in educational, commercial and non-commercial purposes under a Creative Commons attribution 4.0 International License (CC BY 4.0). 